\title{
Obstetric complications: does training traditional birth attendants make a difference?
}

\author{
Patricia E. Bailey, ${ }^{1}$ José A. Szászdi, ${ }^{2}$ and Lucinda Glover ${ }^{1}$
}

ABSTRACT Objective. To assess the effect that a training intervention for traditional birth attendants (TBAs) in Guatemala had on the detection of obstetric complications, the referral of patients with complications to the formal health care system, and, ultimately, those patients' utilization of essential obstetric care services.

Methods. Using a quasi-experimental design, a surveillance system of births was implemented to collect population-based information from 3518 women between 1990 and 1993. All women were interviewed postpartum by physicians. There were three key independent variables in our study: 1) geographical area (intervention community and non-intervention community), 2) time in relation to the training intervention (before or after), and 3) presence or absence of a TBA at the time of the complication. The key dependent variables for women interviewed were 1) development of an obstetric complication, 2) detection of the problem by the TBA, 3) referral to a health facility, 4) compliance with referral, and 5) use of services.

Results. The incidence of postpartum complications decreased after the intervention, controlling for intervention community. On the other hand, after the intervention TBAs were less likely to recognize most maternal complications, and referral rates did not increase significantly. The likelihood of using health care services increased six-fold among women who were not attended by TBAs, and no increase was observed among those who were attended by TBAs. Conclusion. Training TBAs may have had a positive effect on the rate, detection, and referral of postpartum complications. However, the evidence is less convincing for overall increases in the detection of complications, in referral to the formal health care system, and in the utilization of essential obstetric services among women attended by TBAs.

Key words Maternal and child health, health education, Guatemala.

With an estimated 248 maternal deaths per 100000 live births, Guatemala has the third-highest level of maternal mortality in Latin America, after Bolivia and Haiti. In the rural high-

\footnotetext{
1 Family Health International, Research Triangle Park, North Carolina, United States of America. Address correspondence to: Patricia E. Bailey, Family Health International, Research Triangle Park, North Carolina, United States of America; fax: (919) 544-7261; e-mail: pbailey@fhi.org

2 Instituto de Nutrición para Centroamérica y Panamá, Guatemala City, Guatemala.
}

lands of Guatemala the maternal mortality rate is as high as 446 per 100000 (1). One factor contributing to this high rate is the low use of essential obstetric care (EOC), which consists of screening and treatment for problems during pregnancy as well as emergency obstetric services. According to the 1995 Demographic and Health Survey, about $35 \%$ of Guatemalan women deliver with a physician or nurse in attendance, $55 \%$ with a traditional birth attendant (TBA), and $10 \%$ with a family member or no one (2). In the rural highlands of the country almost $80 \%$ of the births occur at home with a TBA, a family member, or no one in attendance.

The Guatemalan TBA is generally an older woman, often with minimal schooling, who lives in the community and is recognized for her experience attending to pregnant women, the birth itself, and caring for the mother and newborn immediately after the birth. TBAs are recognized for providing certain services that the formal 
health system does not, such as an abdominal massage, or sobada. During pregnancy the massage serves to ascertain that the baby is in the right position. A postpartum massage serves to assure that the organs return to their original location. Depending on the community, the TBA might help prepare a hot steam bath (temascal) for the delivery. Some TBAs provide prenatal vitamins, especially if they have received formal training. Currently Guatemala has no professional equivalent to a midwife.

Hospitals in Guatemala reportedly have a capacity to provide services to only $20 \%$ of women giving birth (3). In contrast to this limited capacity of institutions, there are as many as 20 TBAs per 10000 inhabitants, with some $70 \%$ of those TBAs having received some formal training, according to published and unpublished reports (4). ${ }^{3}$ TBAs who have not received formal training may be particularly fearful of recrimination if they refer patients with complications to the formal health care system. ${ }^{4}$ Women often fear hospitals, especially when they have never been to one, and they associate hospitals with death, surgery, or sterilization. At hospitals women frequently encounter a language barrier or receive treatment they perceive as insensitive or harmful (3).

In response to the high maternal mortality levels, the Maternal and Neonatal Health Project was developed in 1990 by the Institute of Nutrition of Central America and Panama (INCAP), located in Guatemala City. The project was financed by the MotherCare Project of John Snow, Inc., in Washington, D.C., with funding from the United States Agency for International Development (USAID)/ Guatemala, and the USAID Regional

\footnotetext{
3 Putney P, Smith B. Study on the practices of traditional birth attendants in the highlands of Guatemala. PRITECH report for USAID Mission/ Guatemala 1989. Unpublished document.

4 Acevedo D, Hurtado E. El papel de las comadronas y proveedores formales en la atención del embarazo, parto y postparto en cuatro comunidades rurales de Guatemala: ¿Complementación o conflicto? Presented at the International Seminar on Population in Central America, University of Costa Rica, 19-21 October 1995, San José, Costa Rica.
}

Office for Central American Programs. The target area was the highlands portion of the department of Quetzaltenango; that highlands area has a primarily indigenous population of about 150000 inhabitants.

The Maternal and Neonatal Health Project designed its interventions to improve maternal and neonatal survival with a theoretical framework that built on four steps: 1) recognition of a life-threatening complication by the woman or by someone else unable to care for the problem, 2) the decision to seek care, 3 ) the ability to access care by surmounting such obstacles as transportation difficulties, cost, or institutional barriers, and 4) the quality of care once services are accessed (5). This study focuses on the first three steps, hereafter called the "management process," and asks, if after training, whether there was: a) an increase in the detection of obstetric complications, b) an increase in referral of women with obstetric complications to the formal health care system, and, ultimately, c) greater utilization of essential obstetric care services.

Given the large number of home births attended by TBAs in this area of Guatemala, training was a major component of the Project's interventions, directed both at the TBAs themselves and at those who trained the TBAs. TBA trainers received instruction to improve their technical knowledge and to introduce them to more effective training techniques. The training of the TBAs themselves emphasized detection, management, and timely referral of the complicated obstetric and neonatal cases that present the greatest risk of mortality. Indications for referral included bleeding, swelling of hands and face during pregnancy, malpresentation, prolonged labor, retained placenta, asphyxia, postpartum bleeding, and maternal and neonatal infections. The training also discouraged potentially harmful practices such as the abuse of oxytocic injections and the use of alcoholic beverages by the parturient during labor to accelerate labor or "give her strength." (3). Four hundred TBAs were trained in three-day courses over a three-month period, reaching virtually all known TBAs in the area.

To reduce mortality and severe morbidity, either there must be an increase in TBAs' detection of obstetric complications and referral for them or women must recognize danger signs and go to a hospital on their own. To make the hospital environment more welcoming to TBAs and the women they refer, all hospital staff, from the gatekeeper to the physician, were encouraged to welcome the TBA and to allow her to remain with her patient (6). The hospital intervention, which took place in the early stage of the project, in addition to interpersonal skills training, included instruction on the use of protocols for essential obstetric and newborn care, and is discussed in more detail elsewhere $(7,8)$.

\section{MATERIALS AND METHODS}

The Vital Events Registration System was originally designed as an evaluation component to the overall Quetzaltenango Maternal and Neonatal Health Project. The study design included intervention and nonintervention communities, with data collected before and after the intervention. The intervention community consisted of 10 municipalities of the department of Quetzaltenango; the non-intervention community consisted of 5 municipalities of Quetzaltenango and 4 in the adjacent department of San Marcos. Stratified cluster sampling without replacement was also part of the design, where the strata were defined by the size of the population and distance from the closest hospital, the San Juan de Dios Western Region General Hospital, located in the departmental capital city of Quetzaltenango (commonly known as Xela). The data were weighted because the number of clusters per strata was not proportional to the population of each stratum. ${ }^{5}$

\footnotetext{
5 Schieber BA, Szászdi JA. Final report of surveillance of pregnancy outcomes in Quetzaltenango health area 1991-93. Guatemala City: Instituto de Nutrición de Centro América y Panamá, Internal publication, 1994
} 
FIGURE 1. Study sample and its subgroups, intervention to train traditional birth attendants, Guatemala,1990-1993

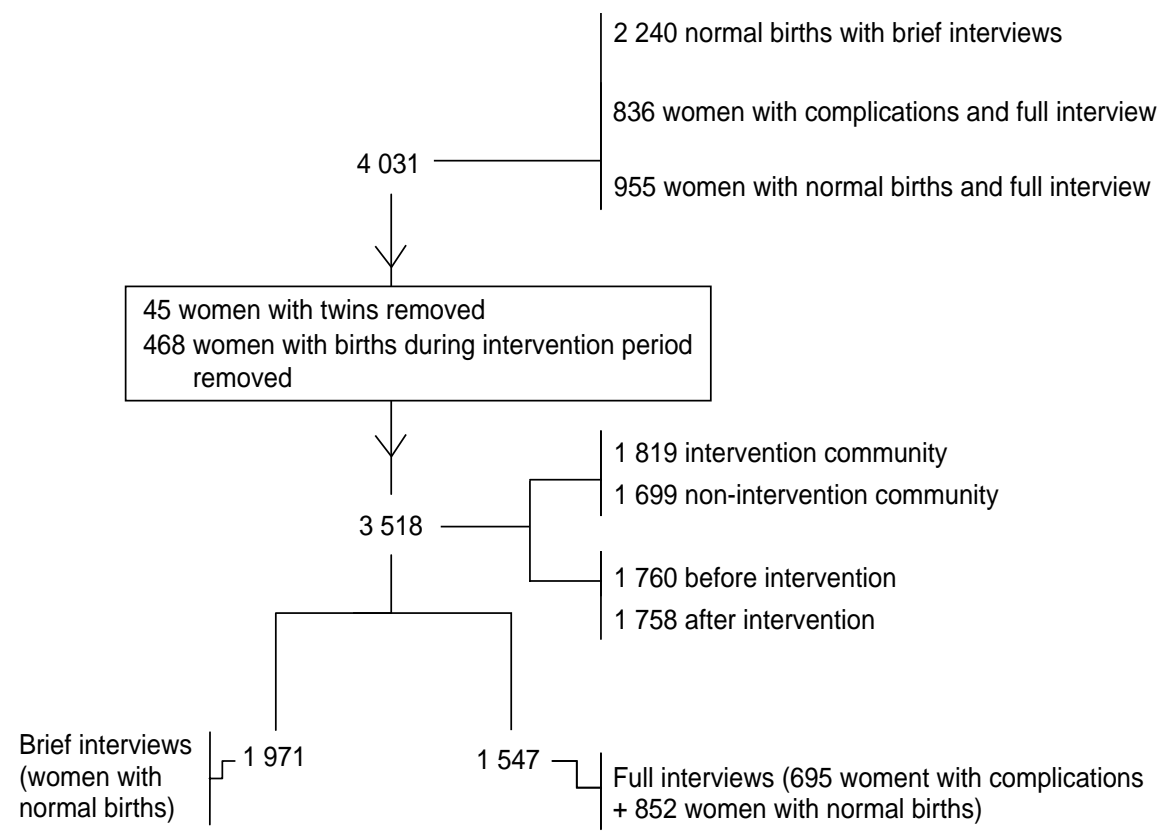

Between July 1990 and May 1993, interviewers visited periodically all households in the selected clusters to determine if a birth had occurred during this study period, conducting either a brief or full interview. Births were grouped as those that occurred during the pre-intervention period, the intervention period itself, or the postintervention period. For each birth, the interviewers-all physiciansdetermined whether the pregnancy and/or birth had been normal or complicated. They collected information for a census of 4031 births, including both members of twin sets (Figure 1). The interviews were of two types: a brief series of questions for 2240 women with normal births and a longer set of questions (the full interview) for all 836 women with complications and for 955 women with normal births. For this analysis, 45 mothers of twins were excluded. Also excluded were 468 women who delivered during the three-month period of the TBA training since training status of the TBA in attendance could not be determined. Of the remaining 3518 women, 1819 lived in the intervention community and 1699 in the non-intervention community.
Full interviews were used from 1547 mothers, comprised of: a) 695 women who reported a complication associated with pregnancy, delivery, the postpartum period, or her newborn and b) 852 women who had normal births (Figure 1). About $30 \%$ of the 2823 women with normal births completed a full interview. The remaining 1971 women with normal births completed a brief interview, providing only the information necessary to determine that they experienced no complication as well as their residence (intervention community or non-intervention community) and time of interview (before or after the intervention). We authors have no reason to suspect that the women who were interviewed at length were significantly different from those who were not. Those who were interviewed at length were chosen systematically (for example, every third woman with a normal birth). The estimates of the incidence of morbidities are thus based on the 3518 women, and detection of complications and referral for them is examined for 518 women who experienced an ante-natal, intrapartum, or postpartum complication. The detection and referral for newborn complications is not addressed in this paper, thus, the 177 women with newborn complications only were excluded from these analyses.

SUDAAN software was used to account for the effect of cluster sampling on the calculation of statistical variance (9). Most statistical packages assume simple random sampling when they calculate tests of association; consequently, they report statistical significance generously. SUDAAN uses the chi-square statistic based on log odds ratios to test associations (10). For logistic regression, the Satterthwaite adjusted chi-square statistic and the adjusted Wald F-statistic were used to test for association.

There were three key independent variables in our study: 1) geographical area (intervention community vs. nonintervention community), 2) time in relation to the training intervention (before and after), and 3) presence of a TBA at the time of the complication or not. Complications have been grouped into three periods: antenatal, intrapartum, and postpartum. Antenatal problems include hemorrhage, edema, malpresentation, hypertension, premature contractions, and previous cesarean section(s). The intrapartum period encompasses premature labor, transverse lie, breech presentation, member prolapse, convulsions, maternal exhaustion, hemorrhage, premature rupture of membranes, fever, and previous cesarean section(s). The postpartum period includes hemorrhage, fever, endometritis, sepsis, convulsions, and retained placenta. Fetal and newborn morbidities include low birthweight/prematurity, asphyxia, neonatal sepsis, respiratory infections, tetanus, and absence of fetal movement. Because cell size becomes small in Table 5, the aggregate of antenatal, intrapartum, and postpartum complications is designated "maternal" complication and is shown in addition to the three separate morbidity groups. Since the focus of this paper is more behavioral than clinical, the unit of analysis is the woman rather than the complication. Because some women reported more than one complication, 
the most life-threatening problem of each phase of pregnancy and delivery was identified and the management of only that problem was examined. If a woman reported problems during more than one period, a second hierarchy was devised across time periods of pregnancy, where, for example, if a woman reported a complication in both the delivery (intrapartum) period and the postpartum period, the more life-threatening of the two was chosen. A description of the hierarchies of complications within and across time periods is given elsewhere (11).

To determine the odds of a complication occurring or a step in the management process taking place, logistic regression was used. The reference groups for the independent variables are: before the intervention, the nonintervention community, and TBA present at the time of the complication (when examining the utilization of health services). In Table 2 (probability of having a complication) and in Table 3 (management of most serious maternal complication) we tested for interactions where alpha $=0.10$. If the interaction was significant, we show the comparison between the two communities before and after the intervention.

\section{RESULTS}

\section{Complication incident rates}

Overall, $20 \%$ of women reported one or more complications (Table 1). About $49 \%$ of the women reporting a complication reported only one, 31\% reported two, and $20 \%$ reported three or four (data not shown). Fetal or newborn complications are included in this summary of multiple morbidities but are excluded from all the other analyses in this paper.

Almost 9\% of women reported complications during the antenatal period, $8 \%$ during delivery, and $4 \%$ during the postpartum period (Table 1). In the intervention community, only one change from before to after the intervention was significant. That was a decrease in postpartum complications, which went from $7.4 \%$ to $2.5 \%$.

TABLE 1. Percentage of women with maternal or newborn complications before or after the intervention to train traditional birth attendants, Guatemala, 1990-1993

\begin{tabular}{|c|c|c|c|c|c|c|c|}
\hline \multirow[b]{2}{*}{ Complication $^{a}$} & \multirow[b]{2}{*}{$\begin{array}{c}\text { Total } \\
\text { (3 } 518 \text { women) } \\
\%\end{array}$} & \multicolumn{3}{|c|}{ Intervention community } & \multicolumn{3}{|c|}{ Non-intervention community } \\
\hline & & $\begin{array}{c}\text { Before } \\
(n=941) \\
\%\end{array}$ & $\begin{array}{c}\text { After } \\
(n=878) \\
\%\end{array}$ & $P$ value & $\begin{array}{c}\text { Before } \\
(n=819) \\
\%\end{array}$ & $\begin{array}{c}\text { After } \\
(n=880) \\
\%\end{array}$ & $P$ value \\
\hline Antenatal & 8.6 & 8.2 & 6.4 & .34 & 9.2 & 10.9 & .19 \\
\hline Intrapartum & 8.0 & 9.7 & 7.3 & .32 & 5.7 & 8.7 & $.03^{b}$ \\
\hline Postpartum & 4.1 & 7.4 & 2.5 & $.02^{b}$ & 3.6 & 2.4 & .24 \\
\hline Neonatal & 9.7 & 9.8 & 10.3 & .71 & 7.6 & 11.0 & .07 \\
\hline Overall & 20.2 & 22.6 & 18.6 & .28 & 17.8 & 21.3 & .11 \\
\hline
\end{tabular}

${ }^{a}$ Complication groups are not mutually exclusive.

b Significant finding.

This decrease occurred among women who reported postpartum hemorrhage, fever, and/or convulsions. Conversely, in the non-intervention community, there was also only one significant change, with intrapartum complications increasing from $6 \%$ to $9 \%$. The regression model 3 in Table 2 confirms the first analysis: there was a $58 \%$ decrease (odds ratio 0.42 ) in post- partum complications after the intervention as compared with before, while controlling for intervention community. When modeling intrapartum complications (model 2 in Table 2), the interaction of community and time period was significant and shows a $90 \%$ increase (odds ratio 1.90) in the odds of an intrapartum complication in the intervention community as compared

TABLE 2. Percentage of women with a complication and probability (odds ratio and $95 \%$ confidence interval) of having a complication, controlling for time period and intervention community, Guatemala, 1990-1993

\begin{tabular}{|c|c|c|c|c|}
\hline Time period of complication & $\begin{array}{l}\text { Sample } \\
\text { size } \\
n\end{array}$ & $\begin{array}{c}\% \text { of } \\
\text { women with } \\
\text { complication }\end{array}$ & Odds ratio & $\begin{array}{c}95 \% \\
\text { confidence } \\
\text { interval }\end{array}$ \\
\hline \multicolumn{5}{|l|}{ Model 1 antenatal } \\
\hline Before the intervention & 1760 & 8.6 & Reference & \\
\hline After the intervention & 1758 & 8.5 & 0.97 & $0.68-1.38$ \\
\hline Non-intervention community & 1699 & 10.0 & Reference & \\
\hline Intervention community & 1819 & 7.4 & 0.71 & $0.45-1.12$ \\
\hline \multicolumn{5}{|l|}{ Model 2 intrapartuma } \\
\hline \multicolumn{5}{|l|}{ Before the intervention } \\
\hline Non-intervention community & 819 & 5.7 & Reference & \\
\hline Intervention community & 941 & 9.7 & 1.90 & $1.15-3.15^{b}$ \\
\hline \multicolumn{5}{|l|}{ After the intervention } \\
\hline Non-intervention community & 880 & 8.7 & Reference & \\
\hline Intervention community & 878 & 7.3 & 0.91 & $0.52-1.59$ \\
\hline \multicolumn{5}{|l|}{ Model 3 postpartum } \\
\hline Before the intervention & 1760 & 5.7 & Reference & \\
\hline After the intervention & 1758 & 2.4 & 0.42 & $0.21-0.81^{b}$ \\
\hline Non-intervention community & 1699 & 3.0 & Reference & \\
\hline Intervention community & 1819 & 5.0 & 1.72 & $0.92-3.21$ \\
\hline
\end{tabular}


with the non-intervention community before the intervention.

\section{Contact with TBAs}

Before focusing exclusively on the women with complications, we compared the 852 women with no complications with the 518 women with maternal complications to determine the extent to which women seek TBAs during pregnancy, in labor, and at delivery. Of the women who did not have a complication, in all three of those periods more than $80 \%$ of the women were attended by a TBA. On the other hand, for women with a complication, the proportion attended by a TBA decreased as the pregnancy progressed, from $86 \%$ during pregnancy to $73 \%$ during labor and $65 \%$ at delivery (data not shown).

\section{Management process of complications}

Given the frequency and life-threatening nature of many complications, appropriate and timely management is essential to saving women's lives. There are five levels of management examined in this section:

1. Was the TBA present at the time the complication occurred?

2. Did the TBA detect the problem?

3. Did the TBA refer the woman with the complication to a health care facility?

4. Did the referred woman and her family comply with the referral?

5. Did the woman use health care facilities (hospital, health center or post, or other services, most of which are private medical services)?

The likelihood of a positive reply to these five questions is examined in Table 3. Interaction terms were also examined for each analysis but are shown only for the first question, presence of a TBA. In the first two rows we see that 124 women with complications in the non-intervention community were interviewed before the inter-

TABLE 3. Percentage of women with complications with TBA was present when the complication occurred, TBA detected the complication, TBA referred the woman, woman complied with the referral, and woman used health care services, and the probablility of each situation, controlling for intervention community and time period, Guatemala, 1990-1993

\begin{tabular}{|c|c|c|c|c|}
\hline Time period of complication & $\begin{array}{l}\text { Sample } \\
\text { size } \\
n\end{array}$ & $\begin{array}{c}\% \text { of } \\
\text { women with } \\
\text { complication }\end{array}$ & Odds ratio & $\begin{array}{c}95 \% \\
\text { confidence } \\
\text { interval }\end{array}$ \\
\hline \multicolumn{5}{|l|}{ Had a TBA present (Model 1)a } \\
\hline \multicolumn{5}{|l|}{ Before the intervention } \\
\hline Non-intervention community & 124 & 72.9 & Reference & \\
\hline Intervention community & 155 & 63.5 & 0.65 & $0.30-1.41$ \\
\hline \multicolumn{5}{|l|}{ After the intervention } \\
\hline Non-intervention community & 127 & 66.6 & Reference & \\
\hline Intervention community & 112 & 75.1 & 1.51 & $0.72-3.15$ \\
\hline \multicolumn{5}{|c|}{ TBA detected complication (Model 2) } \\
\hline Before the intervention & 194 & 80.9 & Reference & \\
\hline After the intervention & 174 & 68.3 & 0.49 & $0.28-0.86^{b}$ \\
\hline Non-intervention community & 184 & 78.0 & Reference & \\
\hline Intervention community & 184 & 72.8 & 0.70 & $0.36-1.33$ \\
\hline \multicolumn{5}{|l|}{ TBA referred woman (Model 3) } \\
\hline Before the intervention & 158 & 43.2 & Reference & \\
\hline After the intervention & 133 & 44.6 & 1.09 & $0.64-1.86$ \\
\hline Non-intervention community & 150 & 38.0 & Reference & \\
\hline Intervention community & 141 & 48.9 & 1.58 & $0.90-2.80$ \\
\hline \multicolumn{5}{|l|}{$\begin{array}{l}\text { Woman/family complied with referral } \\
\text { (Model 4) }\end{array}$} \\
\hline Before the intervention & 64 & 82.8 & Reference & \\
\hline After the intervention & 59 & 62.3 & 0.35 & $0.12-1.03$ \\
\hline Non-intervention community & 57 & 69.0 & Reference & \\
\hline Intervention community & 66 & 77.5 & 1.46 & $0.65-3.27$ \\
\hline \multicolumn{5}{|l|}{$\begin{array}{l}\text { Woman used health care services } \\
\text { (Model 5) }\end{array}$} \\
\hline TBA present & 368 & 37.1 & Reference & \\
\hline TBA not present & 150 & 78.4 & 6.30 & $3.87-10.48^{b}$ \\
\hline Before the intervention & 279 & 48.8 & Reference & \\
\hline After the intervention & 239 & 51.6 & 1.20 & $0.70-2.03$ \\
\hline Non-intervention community & 251 & 52.0 & Reference & \\
\hline Intervention community & 267 & 48.5 & 0.84 & $0.54-1.32$ \\
\hline
\end{tabular}

a The interaction between time period and type of community was included in each of the five models, but only in the first model (Had a TBA present) did it approach statistical significance.

b Significant finding.

vention, while 155 similar women were interviewed in the intervention community. A larger percentage of the women in the non-intervention community were attended by a TBA $(73 \%)$ compared with women in the intervention community (64\%). Although not statistically significant when broken down (due to small cell sizes), we see diverging odds ratios in the first model, which suggests that in the intervention community before the intervention the odds of having a TBA present were lower than in the nonintervention community. However, after the intervention, the odds ratio increased, suggesting an increased likelihood of having a TBA present in 
TABLE 4. Percentage of women who were attended by traditional birth attendant and whose complication was detected and referred, by type of complication, intervention community, and time period, Guatemala, 1990-1993

\begin{tabular}{|c|c|c|c|c|c|c|}
\hline \multirow[b]{2}{*}{ Complication $^{\mathrm{a}}$} & \multicolumn{3}{|c|}{ Intervention community } & \multicolumn{3}{|c|}{ Non-intervention community } \\
\hline & $\begin{array}{c}\text { Before } \\
\%\end{array}$ & $\begin{array}{c}\text { After } \\
\%\end{array}$ & $P$ value & $\begin{array}{c}\text { Before } \\
\%\end{array}$ & $\begin{array}{c}\text { After } \\
\%\end{array}$ & $P$ value \\
\hline \multicolumn{7}{|l|}{ Antenatal } \\
\hline Detected & 83 & 73 & .23 & 81 & 64 & .12 \\
\hline Referred & 51 & 51 & 1.00 & 43 & 41 & .83 \\
\hline \multicolumn{7}{|l|}{ Intrapartum } \\
\hline Detected & 62 & 50 & .30 & 81 & 59 & .06 \\
\hline Referred & 44 & 44 & 1.00 & 44 & 44 & .95 \\
\hline \multicolumn{7}{|l|}{ Postpartum } \\
\hline Detected & 67 & $89^{a}$ & 11 & 97 & $80^{\mathrm{a}}$ & .12 \\
\hline Referred & $35^{\mathrm{a}}$ & $57^{a}$ & .28 & 29 & $33^{a}$ & .83 \\
\hline
\end{tabular}

a Small cell size (cell in which the number in the denominator used to calculate the percentage was $<25$ women).

the intervention community compared with the non-intervention community.

Models $2-4$ in Table 3 include only the women who reported the presence of a TBA at the time of the complication. The likelihood that a TBA detected the complication decreased by half after the intervention. The odds that a woman with a complication was referred (Model 3) did not significantly change, but the elevated odds ratio suggests a tendency toward an increase in referral. Although not statistically significant, a worrisome finding is the decreased likelihood of complying with referral after the intervention (Model 4 ), as the odds ratio of 0.35 suggests. About a quarter of the women who were referred by a TBA did not comply with the referral, citing as the primary reasons their lack of confidence in or distrust of the hospital, transportation difficulties, and inadequate financial resources (data not shown).

Finally, were women more likely to use health services after the intervention? As shown in Model 5 in Table 3, neither the timing of the intervention nor the geographical area (intervention community vs. non-intervention community) predicted use of services, but whether a woman sought a TBA did. However, the likelihood that a woman utilized health facilities was six times greater if a TBA was not present at the time of the obstetric complication than if the woman was attended by a TBA.

Do the two significant findings from Table 3 (TBAs' decreased likelihood of detecting problems and the association between the absence of a TBA and increased use of services) uniformly hold across antenatal, intrapartum, and postpartum complications? Table 4 shows the percentage of women with complications who had contact with a TBA and whose complication was detected and ultimately referred. As is shown in the first row of numbers, the percentage of women whose antenatal complication was detected decreased in both the intervention and non-intervention communities although neither decrease was statistically significant. The percent of women referred did not significantly change over time in either community. A similar pattern exists for intrapartum complications. And while with the postpartum complications there is a different pattern-one in a positive direction-many of those cell sizes are small.

Table 5 examines the relationship between the presence of a TBA and the utilization of services, before and after the intervention. Small cell size prevents the breakdown into intervention and non-intervention communities.
The top row consists of women who were attended by a TBA. The percentage who utilized services did not change after the intervention. However, among women who were not attended by a TBA, the use of services significantly increased, especially for postpartum complications. This suggests that women and their families increasingly recognize problems that they are unable to resolve at home and seek essential obstetric care services.

\section{DISCUSSION}

An actual reduction in morbidity or complications may be an unrealistic indicator for the evaluation of TBA training because there is little that TBAs can do to prevent an antenatal or intrapartum complication. The TBAs' greatest potential for effective intervention is during the postpartum period, especially in cases of hemorrhage or infection, which is where this study did detect a positive change. Not only did the proportion of women experiencing postpartum complications decrease, but detection of postpartum complications and referral of these women also appear to have increased in the intervention community (with the caveat of small numbers). Given that postpartum hemorrhage may be the most frequent cause of maternal death in Guatemala, this result bodes well for decreasing levels of maternal mortality.

The most paradoxical finding in this study was the decline in the detection of complications after the TBA training, especially in light of O'Rourke's findings for the hospital training on interpersonal skills and the use of protocols for essential obstetric and newborn care $(7,8)$. Among the women referred by TBAs and attended at the San Juan de Dios Western Region General Hospital, O'Rourke observed that TBAs' ability to detect certain complications, specifically prolonged labor and preterm labor, improved after the training. However, because there were no statistically significant differences between the intervention and nonintervention communities, the im- 
TABLE 5. Percent of women with obstetric complications who went to health facilities, in terms of the presence of a TBA during the complication, type of complication, and time period (before or after the intervention), Guatemala, 1990-1993

\begin{tabular}{|c|c|c|c|c|c|c|c|c|c|c|c|c|}
\hline & \multicolumn{3}{|c|}{ Maternal complications ${ }^{\mathrm{a}}$} & \multicolumn{3}{|c|}{ Antenatal complications } & \multicolumn{3}{|c|}{ Intrapartum complications } & \multicolumn{3}{|c|}{ Postpartum complications } \\
\hline & $\begin{array}{c}\text { Before } \\
\%\end{array}$ & $\begin{array}{c}\text { After } \\
\%\end{array}$ & $P$ value & $\begin{array}{c}\text { Before } \\
\%\end{array}$ & $\begin{array}{c}\text { After } \\
\%\end{array}$ & $P$ value & $\begin{array}{c}\text { Before } \\
\%\end{array}$ & $\begin{array}{c}\text { After } \\
\%\end{array}$ & $P$ value & $\begin{array}{c}\text { Before } \\
\%\end{array}$ & $\begin{array}{c}\text { After } \\
\%\end{array}$ & $P$ value \\
\hline TBA not present & 71.6 & 87.5 & $.03^{\mathrm{b}}$ & 78.1 & 88.4 & .33 & 77.3 & 84.1 & .56 & 58.3 & $96.5^{c}$ & $.01^{\mathrm{b}}$ \\
\hline Overall & 48.8 & 51.6 & .65 & 51.4 & 53.7 & .79 & 48.0 & 41.1 & .31 & 42.8 & 59.8 & .13 \\
\hline$P$ value ${ }^{d}$ & $<.01$ & $<.01$ & & .01 & $<.01$ & & .02 & $<.01$ & & .02 & $<.01$ & \\
\hline
\end{tabular}

a Maternal complications are a combination of all antenatal, intrapartum, or postpartum complications.

b Significant finding.

c Small cell size (cell in which the number in the denominator used to calculate the percentage was $<25$ women).

${ }^{\mathrm{d}} P$ value in the last row is for the analysis of having a complication (yes/no) by whether a TBA was present (yes/no), selecting for the before intervention group (or after intervention group), and type of complication.

provement could not be attributed to the training (7).

The TBAs' detection of obstetric complications was reported by the women to our study's physician interviewers. It is possible that direct interviews with the TBAs themselves would provide another perspective. The evidence of little or no increase in referral rates was a disappointment to the project, especially since O'Rourke's hospital data indicated that the number of women reporting that they were referrals increased by more than $200 \%(7,8)$. However, the large percentage increase in the number of referrals at the hospital was based on small numbers. When those numbers were compared as rates over time at the community or population level, a significant increase could not be shown. To increase referral rates we must also learn from women's reluctance to comply with referral. Given that the most frequent reason for women's not complying was a lack of confidence in or a distrust of the hospital, it behooves the public health community to tailor interventions to address this potential barrier to the use of services. Environmental factors such as the political unrest of guerrilla activity may have also contributed to the reluctance of women to comply with referral as well as to use services, especially if referral meant travel at night. Our study highlights the difficulty of evaluating, in isolation, the effectiveness of TBAs since their poten- tial for effectiveness is a function of the effectiveness of the overall system within which they work.

If women's lives are to be saved, it is not sufficient to just have recognition of problems, referral, and compliance. Women with obstetric complications must also have access to essential obstetric services and want to use these services. Our data suggest there was a trend toward increased use of hospital obstetric services among women in general. An increase in the use of services was observed after the intervention especially among women who were not attended by TBAs. However, the differences between the intervention and the non-intervention communities appear to be weak. This may be attributed to contamination, a threat to studies of this design, where the training interventions by the hospital staff may have influenced both geographical communities, as both are located in the catchment area of the same hospital. As stated earlier, O'Rourke put forward this argument of contamination when she analyzed hospital data from the same time period as the Vital Events Registration System and found no differences in outcomes, such as referral, between the intervention and non-intervention communities $(7,8)$.

The non-intervention community also changed during the early stages of the study because of "contamination" from new maternal health-related activities by nongovernmental organizations. The change resulted in a delay of some of our interviews, increasing the time between the birth and interview. Although it was not among the variables in this paper, recall bias was demonstrated. ${ }^{6}$ Our original sampling design called for six strata that were later collapsed to four and allowed us to add clusters to the sample. Additional clusters were needed because the number of women with complications during pregnancy that we hoped to identify had been overestimated. These alterations in the design required that the data be weighted. Nevertheless, we authors do not think these methodological problems sufficiently explain the paradoxical finding of the decline in the detection of complications, or the disappointing results of little or no increase in referral or use of health services among women with complications.

The few differences between before and after the intervention may be a function of the short time period that elapsed from the intervention until the post-intervention data collection. One year may be too short an interval to detect changes in behavior or decreases in complication rates. If training focuses on how a TBA should actually intervene when a complication is detected, TBAs could be expected

\footnotetext{
6 Schieber BA, Szászdi JA. Final report of surveillance of pregnancy outcomes in Quetzaltenango health area 1991-93. Guatemala City: Instituto de Nutrición de Centro América y Panamá, Internal publication, 1994
} 
immediately to manage complications differently. However, if TBAs are responding to a more hospitable environment on the part of hospital staff when they refer their patients, a longer time interval may be necessary to observe and measure a change.

Recent studies have questioned the validity of women's self-reports of morbidities, showing that women's reports do not agree with hospital records or medical diagnoses $(12,13)$. Since our focus is the number of complications and how they are managed, overreporting or underreporting of complications would certainly affect the magnitude of the incident rates, and smaller or larger numbers would, respectively, weaken or strengthen statistical power. However, there is no reason to believe that such misreporting would not be uniform across the communities and time periods in this study.

This study contains very mixed findings with regards to the impact of training TBAs on the detection and referral of women with obstetric complications. Nevertheless, in a region such as the highlands of Guatemala, where as many as $80 \%$ of the births take place at home, those in the community who do attend births, whether TBAs or family members, must be cognizant of the signs of danger. The study does point to a dramatic increase in the use of hospital services among women with complications who had no contact with a TBA. These women perceived the need for care on their own and went directly to health care facilities. They may be women who never would have sought a TBA because they live close to a hospital, may have had a previous favorable experience with the facilities, or may be part of an urbanization or modernization process, of which increased hospital care is an element. Although this change is clearly not attributable to the training of TBAs, it might be attribut- able to the women's perception that the facilities had increased the quality of their care. Whatever the cause for this change, it is encouraging to see an increase in the number of women and their families recognizing the need to seek institutional care and acting accordingly. As a result of these findings and others, MotherCare subsequently sponsored additional activities, over another five-year period beginning in 1994. This subsequent project cycle targeted the community with radio spots as well as applying other information, education, and communication strategies that promoted a reduction in maternal and neonatal mortality. Other high priorities included intense training of facility staff in the treatment of obstetric emergencies and a continuation of efforts to improve relationships between hospital staff and TBAs to make hospitals more family- and TBAfriendly in Quetzaltenango as well as neighboring departments.

\section{REFERENCES}

1. Medina H. Mortalidad materna en Guatemala. Guatemala, Guatemala: Ministerio de Salud Pública y Asistencia Social, Departamento de Salud Maternoinfantil; 1989.

2. Macro International. Guatemala: Demographic and Health Survey 1995. Calverton, Maryland: Macro International; 1996.

3. Schieber BA, Delgado H. An intervention to reduce maternal and neonatal mortality. Guatemala City: Instituto de Nutrición de Centro América y Panamá/Pan American Health Organization; 1993. (INCAP Publication M1-003).

4. Leedam E. Traditional birth attendants. Int J Gynecol Obstet 1985;23:249-274.

5. Koblinsky M. On the pathway to maternal health-results from Indonesia. MotherCare Matters 1995;5(1):1-3.

6. MotherCare. MotherCare's integrated efforts for improving maternal health careexamples from three demonstration projects. MotherCare Matters 1997;6(4):4-23. Panam 1995;119(6):503-514.
7. O'Rourke K. The effect of hospital staff training on management of obstetrical patients referred by traditional birth attendants. Int J Gynecol Obstet 1995 Jun;48 Suppl:S95-S102.

8. O’Rourke K. Evaluación de un programa de capacitación de parteras tradicionales en Quetzaltenango, Guatemala. Bol Oficina Sanit

9. Shah B, Folsom RE, Harrell FE, Dillard CN. Survey data analysis software for logistic regression: work assignment 74, final report. Research Triangle Park, North Carolina: Research Triangle Institute; 1984.

10. Koch GG, Freeman DH, Freeman JL. Strategies in the multivariate analysis of data from complex surveys. International Statistical Review 1975;43:59-78.

11. Bailey PE, Szászdi JA, Scheiber B. Analysis of the Vital Events Reporting System of the Maternal and Neonatal Health Project, Quetzaltenango, Guatemala. MotherCare Matters 1996;5(4):13-18
12. Stewart MK, Festin M. Validation study of women's reporting and recall of major obstetric complications treated at the Philippine General Hospital. Int J Gynecol Obstet 1995;48 Suppl:S53-S66.

13. Seoane G, Castrillo M, O'Rourke K. A validation study of maternal self reports of obstetrical complications: implications for health surveys. Int J Gynecol Obstet 1998;62(3):229-236.

Manuscript received 15 August 2000. Revised version accepted for publication on 16 October 2001. 
RESUMEN Objetivo. Evaluar el efecto que tuvo una intervención para adiestrar a las parteras tradicionales (PT) en Guatemala sobre la detección de complicaciones obstétricas, la remisión de las pacientes con complicaciones al sistema oficial de salud y, por último, la utilización de servicios de atención obstétrica esencial por estas pacientes.

Las complicaciones obstétricas: ¿se produce alguna diferencia cuando se adiestra a las parteras tradicionales? vigilancia para nacimientos a fin de obtener información poblacional de 3518 mujeres entre 1990 y 1993. Todas las mujeres fueron entrevistadas después del parto. Fueron tres las variables independientes clave en nuestro estudio: 1) lugar (comunidad expuesta o no expuesta a la intervención), 2) momento en relación con la intervención educativa (antes o después) y 3) presencia o ausencia de una PT en el momento en que se presentó la complicación. Las variables dependientes clave en el caso de las mujeres entrevistadas fueron 1) aparición de una complicación obstétrica, 2) detección de la complicación por la PT, 3) remisión a un centro de salud, 4) cumplimiento de la remisión y 5) uso de servicios.

Resultados. La incidencia de complicaciones después del parto disminuyó después de la intervención, una vez efectuado el ajuste según el tipo de comunidad (expuesta y no expuesta a la intervención). Por otra parte, después de la intervención fueron menores las probabilidades de que las PT detectaran la mayoría de las complicaciones maternas y no se observó ningún aumento significativo del número de remisiones. Las probabilidades de usar los servicios de salud aumentó seis veces en mujeres que no fueron atendidas por una PT, y no se observó ningún aumento entre las que sí fueron atendidas por una PT.

Conclusión. El adiestramiento de las PT podría haber ejercido un efecto favorable en cuanto a la tasa y la detección de complicaciones después del parto y la remisión de las mujeres con este tipo de complicaciones. No obstante, hay menos datos a favor de un aumento general de la detección de complicaciones, de las remisiones al sistema de salud formal y del uso de servicios de atención obstétrica esencial entre las mujeres atendidas por PT.

Fred Soper Award in Interamerican Health, 2002

Deadline: June 30, 2002

The Pan American Health and Education Foundation (PAHEF) is seeking nominations for this award, which is granted yearly to an author or a group of authors of a scientific paper providing new insights on a public health topic in Latin America and the Caribbean. The award, which consists of a certificate and US\$ 2500 , is given in honor of Doctor Fred L. Soper, Director of PAHO from 1947 to 1958 and one of the leading figures of the twentieth century in interamerican health. PAHEF manages the Award Fund and keeps a special account for all volunteer contributions it receives for this purpose. Finalists are nominated by the Award Committee, whose members are appointed by PAHO and PAHEF. The final decision is made by the Foundation's Directing Council.

Any study presented by its authors or on their behalf can compete for the award, as long as the following criteria are met. The paper should be a research study, an analysis of new data generated through an experimental or observational study, or a new review of primary data. Multidisciplinary studies, as well as studies on infectious diseases, which were Dr. Soper's main field of interest, are given foremost consideration. All papers nominated for the award must have been published in 2001 in scientific journals listed in Index Medicus or in PAHO's official publications. In addition, the authors must be affiliated with academic institutions or with research or service institutions in Latin America and the Caribbean, including PAHO's collaborating centers. All nominations must be received no later than June 30, 2002.

Address for sending nominations:

Fred L. Soper Award Committee

c/o Pan American Health and Education Foundation

525 Twenty-third Street, N.W.

Washington, D.C. 20037, U.S.A.

Tel.: 202-974-3416

Fax: 202-974-3636

E-mail: pahef@paho.org 